\title{
The experienced impact of systems psychodynamic leadership coaching amongst professionals in a financial services organisation
}

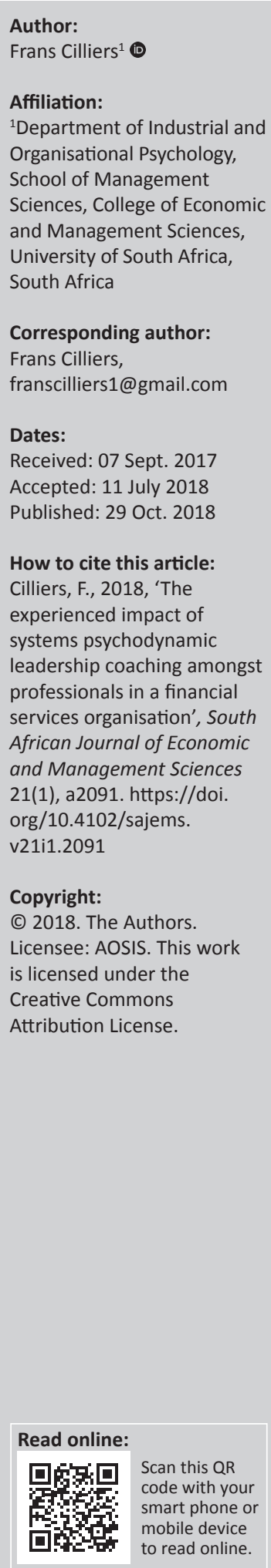

Background: Systems psychodynamic leadership coaching is a depth psychology perspective that provides opportunities for coachees to explore their leadership identity as it manifests in their conscious and unconscious role behaviour.

Aim: The research aim was to explore the experienced impact of systems psychodynamic leadership coaching amongst professionals in a financial services organisation, and to report on how this impact can be understood in the context of the literature guidelines on coaching and leadership effectiveness.

Setting: The research was undertaken in a large South African financial services organisation where individual leadership coaching forms part of the leadership development programme (LDP).

Methods: The research was qualitative, explorative and descriptive in nature. A multi-case approach was used. Sampling was convenient and opportunistic and comprised of 15 charted accountants who attended six 90-min coaching sessions over 12 weeks. Data gathering comprised field notes and coachee essays during and after coaching. Hermeneutic phenomenology was used as the interpretive stance.

Results: Anxiety, task, role, boundaries, authorisation and identity manifested as themes. Coachees explored how their leadership identity was informed by their anxiety and defence mechanisms, how they took up their leadership role, authorised themselves and their colleagues, and managed their boundaries effectively. Compared to the general guidelines for leadership coaching effectiveness and the general indicators for effective leadership, systems psychodynamic leadership coaching seems to add value to leadership effectiveness.

Conclusion: Professionals in this financial services organisation experienced systems psychodynamic leadership coaching as demanding, challenging and yet fulfilling towards the exploration of their leadership identity. It seems that systems psychodynamics, as coaching stance, created a safe and good-enough container for these financial professionals to explore their own unconscious leadership behaviour and to gain a significant level of understanding and awareness of their own anxiety and defensive behaviours in their interaction with followers.

\section{Introduction}

As a field of study, leadership has an extensive and voluminous 100-year-old literature base, containing an overwhelming proliferation of paradigms, definitions, models, theories, concepts, terms, outcomes, competencies and measurement instruments (Nohria \& Khurana 2010; Northouse 2014; Veldsman \& Johnson 2016). According to Bennis (2007), this gives evidence of the complexity, dynamics and elusiveness associated with leadership, which creates confusion amongst researchers and practitioners.

In general, leadership can be defined as the activity to willingly involve oneself, influence, coordinate and guide people's organisational activities towards attaining positive goals and outcomes for the organisation, according to the existing context and set strategy (Cooper 2005; Leonard et al. 2013; Meyer \& Boninelli 2007). Research on the psychology of leadership is mostly informed by a humanistic conceptualisation and positivist operationalisation. Leadership research gives evidence of the psychometric relationship between leadership styles and behaviours, and organisational outcomes (Kaiser, Hogan \& Craig 2008). For example, a task orientation is applicable where there is control over a situation, a people orientation where 
control is moderate, consideration where job satisfaction is desirable, structure where effectiveness and containment are needed and a transformational stance where inspiration and commitment are needed. Presently, the leadership literature focuses strongly on transformational leadership in a quest to understand how leaders need to cope in the 21st century and postmodern era (Veldsman \& Johnson 2016), amidst never-before-experienced complexity such as the new economy, globalisation, mergers and acquisitions, chaos, paradox, diversity, power, risk and limited resources (Bennis \& Sample 2015; Crevani \& Endrissat 2016; Elkington \& Booysen 2015; Klein, Rice \& Schermer 2009).

Leadership coaching has developed as a way of assisting leadership in coping with its complexity (Passmore, Peterson \& Freire 2013). Coaching's importance is reflected in it being referred to as the fastest growing profession and the single most influential input in the modern organisational and corporate environment (Kahn 2014). Leadership coaching is generally defined as a regular, short-term, highly focussed, contractual organisational learning opportunity. It involves a facilitating (helping) relationship between a coachee, who has managerial and leadership authority and responsibility in an organisation, and a coach, who uses psychological and behavioural paradigms, models, techniques and methods to assist the coachee to develop relevant leadership behaviours and thereby improve organisational effectiveness (Brunning 2006; Hawkins \& Smith 2013; Kets de Vries, Korotov \& Florent-Treacy 2007; McKenna \& Davis 2009; Paice 2012). Of the demands on leadership (Nohria \& Khurana 2010), coaching focusses on the people aspects of insight, learning, growth and change in the self and between the self and the other. Thus, the goal of leadership coaching can be framed as to significantly optimise the leader's effectiveness on the intrapersonal and interpersonal levels. This refers to selfleadership, leadership of the other (colleagues and followers in dyads and teams) and leadership in the organisation as a system (Greif 2007). Coaching effectiveness is seldom linked to indicators for effective leadership, such as those formulated by the Kellogg Foundation (Development Guild 2015).

Although the merit and value of leadership coaching are accepted in practice (Page \& De Haan 2014), it lacks solid research evidence to establish its identity as a scientific intervention in the field of organisational development (OD) (Kahn 2014). Theoretically, all the major psychological paradigms have been applied to leadership coaching, for example, psychodynamics, behaviourism, cognitive psychology, humanism, existentialism and neuropsychology (Bachkirova 2011; Bluckert 2006; Brown \& Brown 2012; Passmore et al. 2013; Peltier 2009). However, in practice, research mostly reports on coaching programmes linked to positive psychology constructs (Cilliers 2011; Page \& De Haan 2014; Western 2012), such as those applied in the goal, reality, options, will (GROW) model (Stout Rostron 2009). Specifically, emotional intelligence (Dippenaar \& Schaap 2017), happiness (Biswas-Diener \& Dean 2007), resilience (Maddi \& Khoshaba 2005) and flourishing (Grant 2007) are included in positive psychology coaching programmes. The published coaching research on the aforementioned positive psychology constructs show face validity in terms of enhancing the behavioural constructs it sets out to develop (Dippenaar \& Schaap 2017).

In the present research project, the authorities of a financial services organisation wanted to extend their leadership coaching offering with (amongst others) a model that helps leaders understand the complexity of leadership's individual and organisational systemic role identity explored from an unconscious perspective'. The researcher was invited to make a presentation on systems psychodynamic leadership coaching (SPLC), which was accepted with the request to report back to the organisation about the impact of this coaching stance. Thus, the problem statement of this research project was formulated as follows: what is the experienced impact of SPLC amongst professionals in a financial services organisation, and how can this impact be understood in the context of literature guidelines on coaching and leadership effectiveness?

\section{The motivation for systems psychodynamic leadership coaching}

Because of the huge pressure on and insecurities in financial services organisations in terms of performance and ethics (Kahn 2014), it is difficult to single out one of the mainstream leadership theories (Kets de Vries et al. 2007) as the most appropriate basis for the coaching of its leaders. Mainstream theories include the contingency, personal attribute, trait, competency, situational and transactional or transformational leadership perspectives (Nohria \& Khurana 2010). Systems psychodynamic leadership coaching offers an open-systems approach focussing on the exploration of conscious and unconscious behaviour relevant to how the coachee takes up the role of leader as part of the larger systemic dynamic, while authorising the self and others and managing the relevant boundaries in service of the leadership task (Newton, Long \& Sievers 2006). Next, SPLC was contrasted to other leadership coaching models with the following arguments. Many leadership coaching programmes are not based on any informing leadership framework or definition (Beck 2012). The learning approach in the mainstream leadership coaching programmes is simplistic, linear (working from normal to optimal), reductionist (focussing on evidence-based outcomes) (Western 2012) and focussing on behavioural change, thus excluding the holistic, systemic, existential experiences, characteristic of the complexity of human experience in organisational and social systems (Western 2012). Furthermore, traditional models focus mostly on rational and conscious behaviour, thus ignoring the impact of irrational and unconscious behaviour (Nohria \& Khurana 2010). A structured step-wise approach is followed, thereby limiting the coachee's movement towards their specific learning dynamic (Passmore et al. 2013). Especially in programmes presented from a positive psychology perspective, leadership is defined from one selected theory and then framed as an individual phenomenon, thus ignoring 
leadership as a systemic phenomenon (Bennis 2007; Kahn 2014). Positive psychology coaching programmes focus on positive behaviour, thereby excluding leaders' negative experiences, such as loneliness, attacks, envy, narcissism and performance anxiety. These programmes also accentuate personal development, thus denying the shadow side of leadership and toxicity, which often leads to the derailment of leaders (Western 2012).

\section{Systems psychodynamics}

Systems psychodynamics (SP) has its roots in depth psychology, Freudian systemic psychoanalysis, group and object relations theory and systems thinking (Kets de Vries et al. 2007). Systems psychodynamics is defined as the scientific study towards the understanding of the manifestation of unconscious and dynamic behaviour in organisations, especially about leadership and authorisation (Colman \& Bexton 1975; Colman \& Geller 1985; Cytrynbaum \& Noumair 2004). The SP leadership philosophy is conceptualised in terms of the systemic identity, taking up the role of leader, working on a given primary task and being authorised to manage the self and the other on the boundary between what is inside versus outside (Huffington et al. 2004; Stapley 2006).

Systems psychodynamics interprets the present voluminous amount of leadership theories and its constant deconstruction as compulsiveness and an unconscious defence against the anxiety of facing the complexity of the leadership role, its relationships and relatedness (Czander 1993; French \& Simpson 2015). Systems psychodynamics sees leadership as not belonging to an individual or a group and states that it cannot be confined to a set theory of interactions, rules, guidelines or habits. Rather, leadership is seen as a psychosocial influencing dynamic (Kets de Vries 2006). Western (2013) explains that (1) 'psycho' refers to the psychodynamics of leadership happening within and between people-leadership and followership stimulate intrapsychic, unconscious and emotional responses within and inter-relational dynamics between employees; (2) 'social' refers to the social construction and relational dynamics of leadership, power and authority, control of material and symbolic resources, use of knowledge and technology as manifesting in organisational history, discourses, culture and politics; (3) 'influencing' refers to the agency to influence the other, drawing on a wide array of resources such as personality and coercive power; (4) 'dynamic' refers to the forever fluid movement of the social leadership-followership process, which can't be reduced to skills, competencies or a way of being.

\section{Systems psychodynamic leadership coaching}

The primary task of SPLC is to provide psycho-educational and developmentally focussed learning opportunities for coachees, to explore the self and the prevailing organisational dynamics as an open system (including structural aspects such as design, division of labour, boundaries, the primary task, levels of authority, reporting relationships and relatedness) and the manifestation of their own unconscious systemic behaviour (primitive, social and system domain defences) (Armstrong \& Rustin 2015; Beck 2012; Brunning 2006; Kets de Vries 2006; Neumann, Kellner \& DawsonShepherd 1997; Newton et al. 2006; Sandler 2011). Systems psychodynamic leadership coaching focusses on consciousrational, unconscious-irrational and the congruenceincongruence between these, the manifesting anxiety and its defensive structures on the systemic micro- (individual), meso- (group) and macro- (organisational) levels (Campbell \& Huffington 2008; Hirschhorn 1993; Kets de Vries 2014). Anxiety is accepted as the driving force (dynamo) of the relationship and relatedness between leadership and followership. Defensive structures manifest in the systemic social unconscious as basic assumptions of dependence, fight-flight, pairing (Bion 1961), me-ness and one-ness or we-ness (Fraher 2004), as well as defences such as splitting, introjection, suppression, denial, projection, projective identification and transference (Blackman 2004). The coachee's leadership identity as observed, experienced and represented in the mind, is informed by how the role is taken up and the nature of the experienced authorisation, while managing the boundaries between the self and the other in the service of the primary task (Cytrynbaum \& Noumair 2004). 'Task' refers to the basic component of work and can manifest as adhering to the primary task (indicating contained anxiety) or as diversions into off-task and anti-task behaviour (indicating, e.g., performance anxiety) (Czander 1993). 'Role' refers to the boundary surrounding work and position and between the coachee and the other (Stapley 2006). 'Authorisation' refers to the formal and official right to perform a task, bestowed from above (the organisation, manager, leader), the side (colleagues), below (subordinates) and from within (self-authorisation) (Hirschhorn 1997). 'Boundary' refers to the physical or psychological demarcation and differentiation, observable or subjective, acting as the space around and between parts of the system (e.g. time, space and task) (Cytrynbaum \& Noumair 2004). Transactional analysis adds the constructs of the systemic ego states of parent, adult and child, script development and games (Erskine 2010; Tangolo 2015; Tudor \& Summers 2014), explaining the coachee's communication in significant relationships.

Operationally, the SP coach provides an emotionally contained and transitional space to the coachee's experiential exploration of the self in the role as leader (Clarke, Hahn \& Hoggett 2008). The coach attends to the coachee's reality testing, cognitive functioning (abstractions, differentiations), affective functioning (emotional relatedness to the self and the other), experienced anxiety and use of individual, social and system domain defensive (differentiated between the neurotic, psychotic and the perverse) and object relations, vertical with authority (based on the transference from parental figures), and horizontal with colleagues (based on the transference from siblings) (Newton et al. 2006). The coachee's role is analysed by differentiating between the three role parts of normative (the rational, objectively measureable content), existential (how they believe they are 
performing based on their introjections (their unconscious internalised and transferred feelings, attitudes and values that belong to the external environment) and phenomenal roles (how they believe they perform as experienced by colleagues and others based on their received projections) (Obholzer \& Roberts 1994). Incongruence between the three role parts indicates role anxiety, which could manifest as freefloating, survival, performance, paranoid or persecutory anxiety (Blackman 2004). At the same time, their valence is studied, defined as one's unconscious tendency or propensity to internalise, collude with and respond to the projections of the other and to take on a similar informal role repeatedly in groups dependant on one's object relations and social identity (Beck 2012; Sandler 2011). Typically, sessions start with an open invitation such as: 'Tell me about your present experiences in your role as leader'. Sessions do not have specific agendas - rather, they follow the coachee's conscious and unconscious exploration and stay as close as possible to the coachee's immediate role experiences (Armstrong \& Rustin 2015; Kets de Vries 2014). Storytelling and drawings may also be included (Western 2012).

The coach needs to be systems psychodynamically informed, which refers to a high level of training and competence in working with systemic unconscious material, as well as having a dynamic self-insight and being prepared to use the self as an instrument (Huffington et al. 2004; Kets de Vries et al. 2007). The role of the coach is to not take on a guru position but rather a reflective stance from a meta position (Schafer 2003), alert to the coachee's conscious and unconscious behaviour and the manifestation of defensive behaviour without judgement, memory or desire (Beck 2012; Campbell \& Huffington 2008; Sandler 2011). The coach formulates working hypotheses, defined as an integrative statement of 'searching into' the coachee's experiences, which are constantly revisited in the light of further or new evidence (Campbell 2007). Coachees are encouraged to be curious, to free-associate, to explore a variety of related feelings, patterns, defences and representations, including the transferences between coach and leader, and to move between different levels of abstraction in thought (Jaques 1990).

Research on coachees' experiences in SPLC reports in general on coachees' raised awareness of, insight into and understanding of their leadership role identity in their relationships with and relatedness to the organisational system (Chapman \& Cilliers 2008; Cilliers \& Terblanche 2010; Huffington et al. 2004; Kahn 2014; Motsoaledi \& Cilliers 2012; Passmore et al. 2013). Coachees experience a change in their thinking about their representative nature and value in the organisational system and how they authorise themselves and their followers in their complex matrix systems with its constantly changing organisational context and conscious and unconscious psychological boundaries within and between conflicting subsystems (Kets de Vries 2006, 2014; Kets de Vries et al. 2007). Coaching gives them the opportunity to explore the dynamics of taking up their leadership role and the accompanying levels of survival anxiety, feeling disorientated, lost, lonely, doubtful, not good enough and performance anxiety to perform their primary task and manage their relationships with followers effectively (Passmore et al. 2013). Coachees report on working through very real experiences and behaviours as they never expected to play an important role in leadership (Cilliers 2005; Motsoaledi \& Cilliers 2012). These include their unconscious beliefs, fantasies, wishes, conflicts, defences, preferences, competition, rivalry, jealousy, envy, hostility, narcissism, aggression, regression, repetition of previous relationship patterns, valence for attracting specific projections, collusion with and responses to others' projections and containing feelings or objects on behalf of the system (Beck 2012; Brunning 2006; Kets de Vries et al. 2007; Neumann et al. 1997; Newton et al. 2006; Obholzer \& Roberts 1994; Sandler 2011; Stapley 2006).

\section{Research aim and contribution}

The research aim was to explore the experienced impact of SPLC amongst professionals in a financial services organisation and to report on how this impact can be understood in the context of the literature guidelines on coaching and leadership effectiveness. The contribution of this study lies firstly in a rich description of the SPLC experiences of professionals in a financial services organisation. Secondly, this study contributes towards an understanding of the experienced impact of SPLC as a coaching stance, as well as on leadership effectiveness. Thus, the research has intrinsic (in the understanding of the coachees' experiences) and instrumental value (to provide the coaching fraternity with meaningful data about the nature of SPLC as a depth psychology leadership developmental input) (Denzin \& Lincoln 2005).

\section{Methods}

\section{Research design and approach}

The research was qualitative, explorative and descriptive in nature (Thorne 2016). Participatory action research was performed (Wagner, Kawulich \& Garner 2012) to ensure continuous connectivity, effective communication and good working relationships in the research system, as well as to ensure active researcher involvement. Hermeneutic phenomenology was chosen as the interpretive research paradigm (Clarke \& Hoggett 2009). A multi-case approach was used (McLeod 2012; Wilson \& MacLean 2011), focussing on coachees' experiences while undergoing SPLC, delimited in time, place and task, and then studied through observation, documented self-report and comparison (Hollway \& Jefferson 2010).

\section{Setting}

The study was set in a large South African financial services organisation where the OD division provides professional, logistical and administrative opportunities to financial professionals in need of individual leadership coaching. The researcher was requested to serve on the coaching panel to 
conduct chemistry meetings (Stout Rostron 2009), followed by SPLC with interested professional staff members, according to a standard coaching contract consisting of six 90-min sessions over 12 weeks. All sessions were conducted in a boardroom during office hours.

\section{Sampling}

Fifteen professionals voluntarily completed the coaching contract. This number became the purposive and convenient sample (Thorne 2016) for this study. The sample comprised charted accountants appointed on associate director level. There were nine males and six females, five black people, four Indians and six white people, and all were younger than 40 years of age.

\section{Data collection, recording and analysis}

Two data collection methods were used, namely coaching field notes (Thorne 2016) and coachee essays (Wolcott 2001). The field notes, recorded by the coach during and after each session, provided a detailed rendition of the coachees' verbatim and non-verbal behaviour during each coaching session. The common objection against field notes, namely the researcher's subjective perceptions, was compensated for by the researcher's attention to detail during recording (Denzin \& Lincoln 2005). Halfway through and at the end of the coaching contract, each coachee wrote an essay of about five A4 pages on the question: 'What do you experience and what are you learning through coaching in your role as leader in this organisation?' The two methods in combination provided the text for analysis of the coachees' lived experience (Thorne 2016). Simple hermeneutics allowed for the understanding of the content of coachees' experiences during coaching and double hermeneutics allowed for the critical interpretation of their experiences from the SP stance (Clarke \& Hoggett 2009) as it manifested in themes.

\section{Ethicality}

During each individual chemistry meeting the relevant coaching and research ethical aspects were explained to the coachees (Terre Blanche, Durrheim \& Painter 2006). These aspects were informed consent, voluntary participation and withdrawal, privacy and confidentiality. Participants also gave consent for their data to be included in this research project.

\section{Strategies employed to ensure quality data}

Trustworthiness was based on the following aspects (Wagner et al. 2012). In terms of credibility, the researcher is qualified as a systems psychodynamically informed coach. During the research project the researcher received coaching supervision (Kets de Vries et al. 2007) to ensure objectivity and selfauthorisation. The coaching research was approved and authorised by the organisation, and the OD division assisted in ensuring consistency in logistics and practical arrangements. The research evidenced strong and believable validity in its psychological description, which revealed the complexities of how the SP constructs of task, role, authorisation and boundaries manifested and how the dynamic interaction between the constructs informs the coachees' leadership identity. In this research, triangulation was defined as the process of assessing the outcome of research by viewing it from different perspectives and methods, resulting in a convergence of the data to present rich and valid data (Creswell \& Plano Clark 2011; Denzin \& Lincoln 2005; McLeod 2012; Wilson \& MacLean 2011). Methodological and data triangulation referred to the inclusion of field notes and essays as raw data to avoid interpreting already interpreted data. Investigator triangulation (Wagner et al. 2012) was ensured in using peer reviewers (Thorne 2016). Two independent psychologists, not associated with the research project, both SP informed coaches, were asked to review the database and the qualitative findings using their own criteria (Creswell \& Plano Clark 2011). Their positive feedback on the data analysis gave evidence of dependability. Their feedback on saturation provided evidence of internal generalisability (Denzin \& Lincoln 2005). Theory triangulation was attended to by including transactional analysis (as another interpretive stance within the SP paradigm), which added to the richness of ego states operating in the data (see Wagner et al. 2012).

\section{Findings}

The emerging themes were anxiety, task, role, boundaries, authorisation and identity.

\section{Anxiety}

Coachees experienced free-floating anxiety (Blackman 2004). They referred to the organisation's demand to 'become more involved in leadership' - a 'job that I know nothing about' and 'I am not even sure I want it'. They expressed performance anxiety (Blackman 2004) about leadership ('something I have no training in') and existential and separation anxiety in the fear of giving up 'my professional role in thinking about and working with numbers - not with people'). In terms of their dependence on authority figures, they tended to split their authority in the mind (Armstrong 2005) between the coach as the good object (Klein 1997) ('the guru' that 'must help' and 'understand', 'help me make sense out of the confusion of relationships' and 'save me' from not knowing) and their organisational leadership role as the bad object ('they are not helping in this chaos', 'they don't seem to know themselves', 'I doubt if they had any leadership training themselves'). They used fight as a defence against the 'cruel' system for 'allowing them to not know' and 'to struggle' with difficult clients and colleagues. They used flight as a defence to get away from difficult relationships ('I avoid getting involved in issues with people'). They exhibited we-ness when they expressed strong feelings (referred to as 'frustration' and 'annoyance') and me-ness when the individual wanted to distance the self from the larger system, who was supposed to be impressed with his or her professional performance. Their defensive structures (Armstrong \& Rustin 2015) consisted of splitting between the (introjection of the) good 
professional track record, versus the (projection of the) bad of the 'people issues' associated with leadership and regression ('I wish I was still a clerk who [could] just be busy with auditing tasks all the time'). During the sessions coachees explored these anxieties towards differentiating between their own introjected feeling and thinking behaviour, and what the system was projecting onto them. This resulted in projective identification (Klein 1997), which was an awareness they had never felt before ('I realise more and more that I take on so much of other people's stuff', 'it is not easy to do this work'). They explored how their awareness of their dependence and 'my blaming of the firm for my issues', 'stand in my way to develop my own potential'.

\section{Task}

Coachees split their known professional (Charted Accountant) task from their unknown task of leading people. Originally, they attached (Sievers 2009) to the 'simplicity' of the management of client projects while they detached from what they experienced as the 'extremely demanding', 'complex' and 'unpredictable' leadership task. They realised their inclination to avoid the complexity of leadership by using 'flight into control' of the task ('I feel more productive when I check my team's work on paper' vs. 'I feel so out of control when I need to address the conflict in my team'). They learned to differentiate between the primary task of a project and when they 'go off-task', especially when they feel out of control ('I realise that when I am anxious, I want to control even the uncontrollable and then I lose perspective of the [primary] task').

\section{Role}

Coachees experienced conflict between their normative, existential and phenomenal roles (Obholzer \& Roberts 1994), indicating their role anxiety. Intellectually they understood their normative role as a combination of and balance between their professional and leadership roles. Emotionally they 'struggled because I wanted to keep them apart', especially in difficult interpersonal situations 'when I feel my stress skyrocketing'. In their existential role, they were proud of how the firm had recognised their work, their career background, accomplishments, values and personality characteristics as professionals ('what I was trained to do', 'what I prefer' and 'love to do'). They started to realise their regression (Blackman 2004) into the known role was an indication of the anxiety caused by their leadership role. In their phenomenal role, they explored the projections they received from 'the other', such as colleagues, partners and family. This included expectations of being heroes to save the system with their intelligence, 'professionalism', emotional strength and 'resilience', as well as their interpersonal competence and 'empathy'. They learned to become aware when these projections onto them occurred ('when it is not my stuff', 'I am learning that if it feels unreal, I know it is not mine', 'I do not see myself that way', 'it is what people want me to be for them'). The existential-phenomenal role difference indicated to them that their 'identity [was] under attack', which caused them high levels of anxiety. Towards the end, coachees could start to differentiate between what belonged to them (their introjections) and what systemic projections they received from the other.

\section{Boundaries}

Coachees consciously understood the role of organisational time, space and task boundaries. Yet they were often surprised at how their unconscious boundaries (in the mind) influenced their leadership behaviour. This included the boundary between their personal self and their organisational role ('these roles are so different'), between financial professional and leader of others ('it is a totally different ball game'), the psychological boundaries between associate director and partner in the firm ('we are treated as professionals' and then 'act like children towards the parents') and the boundaries between professional leader and client ('they treat me so differently when I am in my leader role'). Some coachees explored their valence (Huffington et al. 2004) to contain 'feelings and stuff' for the other ('it may be part of the role, but it is very difficult' to carry others' projections). A few coachees processed how they moved from being over-bounded (and having impenetrable boundaries) (Czander 1993), which served to contain their performance anxiety, towards using their systemic awareness to 'relax' and try to function with permeable boundaries.

\section{Authorisation}

Coachees understood how they consciously self-authorised (Hirschhorn 1997) and how they were authorised from above by the partners in the firm, from the side by colleagues and from below from their team members. Their 'most significant learning' was the realisation of the frequency and intensity of being unconsciously de-authorised in the system. In their existential role, this happened as a parental transference dynamic (Hindle \& Sherwin-White 2014) in how they heard their superiors (partners in the firm) 'as if he is my controlling father' ('I can hear my parents' voices telling me that I am not good enough', 'I have often been told by my teachers that I will not make it far'). In their phenomenal role, this happened through the processing of their received projections of incompetence ('they withhold important information from me' 'about rules' and 'the right way of doing'). This was often experienced as management's 'type of power play'. Coachees explored the unconscious power dynamics and could start to process their individual systemic valence to play 'the victim' and 'underdog' roles. Good insights were gained from studying how they collude (Armstrong \& Rustin 2015) with systemic power games. For most coachees significant learning took place in self-authorisation based on the differentiation between what belongs to the self and what not and 'not to take responsibility or guilt for the others'. One coachee mentioned, 'I now understand that what I often see as incompetence is much more a case of not being authorised by leadership'. 


\section{Identity}

Coachees struggled to differentiate between and integrate their personal, professional and leader part-identities (Vansina \& Vansina-Cobbaert 2008). They experienced 'confusion', 'being overwhelmed' and high levels of performance anxiety in their new leadership role. This role contained a complexity of irrational expectations - introjections of having to be a 'super competent' 'people's person', as well as unrealistic projections onto them from the organisational system. As young leaders, they became aware of the unconscious dynamic of 'being used' by the organisational system (Campbell \& Groenbaek 2006) to contain and process the organisation's leadership and succession anxiety. Although this caused free-floating anxiety ('it is very confusing', 'I can't process this by myself'), the coachees move towards exploring, disentangling and differentiating between illusion and fantasy on the one hand, and their reality of taking up a leadership role in the context of their own unique personality styles. They were brave to explore and relinquish their ignorance in favour of heightened awareness. They experienced 'relief', 'insight' and authorisation to face the 'below the surface stuff' that 'play such a big role' in their relationships 'at work and at home'.

\section{Discussion}

The research findings are discussed with reference to three sets of data seen as significant for coaching effectiveness in this research, namely (1) the experienced impact of SPLC amongst professionals in this financial services organisation, (2) the experienced impact of SP as a coaching stance and (3) the experienced impact of SPLC explored against the Kellogg Foundation's indicators for effective leadership (see Kets de Vries et al. 2007; Nohria \& Khurana 2010; Passmore et al. 2013; Western 2012).

\section{The experienced impact of systems psychodynamic leadership coaching amongst professionals in a financial services organisation}

In their normative role coachees had cognitively reconstructed leadership into an accessible and workable behavioural repertoire. This reconstruction was made possible by relinquishing the need to study the voluminous amount of literature on leadership theories and models ('MBA style') and to instead experience leadership as a role with many facets such as rational versus irrational, conscious versus unconscious behaviour on the self-other boundary.

To work with and learn about the self through the exploration of anxiety as an unconscious driving force and its defences was surprising to most coachees ('I thought anxiety and defences were for sick people', and 'here we have spent a whole session on trying to understand my defences against my primitive anxiety'). In their existential role coachees explored their introjections about leadership as the impossible task (Cytrynbaum \& Noumair 2004) often linked to negative past experiences with 'my so-called leaders'. Their introjected values, feelings, thinking and expressive behaviours that manifested as their psychological valence contributed to their most profound learning. The exploration of their transferences of relationships with parental figures and siblings from their family of origin into their present leadership role (Winnicott 2006), brought surprising insights in terms of repeated patterns and parallel processes. In their phenomenal role, many coachees explored projection as a phenomenon for the first time in their lives. They were intrigued by the power of their own and their received projections and its capacity to influence one's behaviour through projective identification. Applied to their leadership role, they reported on their significant learning about how they formed unconscious ideas and biases in their relationships with and about their colleagues, direct reports and partners in the firm, based on their family of origin experiences. They gave examples of their growing awareness about how they projected their own unconscious emotional survival and performance anxieties onto their colleagues during meetings and in project management. For many the breakthrough came when they could, in the here-and-now moment, realise and own the projection as 'my own stuff' and even offer an explanation and 'take back my own stuff'. These findings have also been reported in other South African SP coaching research (Chapman \& Cilliers 2008; Cilliers 2005; Cilliers \& Terblanche 2010; Kahn 2014; Motsoaledi \& Cilliers 2012).

The coachees learned about their object relations through the transactional analysis interpretations (Tudor \& Summers 2014). They reported how they have framed the construct leadership as the demanding and controlling parent in the mind and how they then, in a defensive reaction, took on a rebellious-child response. It took hard work to disentangle from the hooked parent-child engagement in the mind and to shift to adult-adult communication to ensure a balanced and realistic conceptualisation of leadership. They also reported on using their coaching insights to diagnose their project and team cultures. They realised that the firm's prevailing culture was mainly experienced as the critical parent with almost no caring-parent behaviour manifesting. A few coachees started to address this awareness in their projects by stimulating positive storytelling about leaders and leadership, to deconstruct the negative projections onto leadership as a role, as well as onto leaders as people. No research could be traced where transactional analysis was used as an interpretive stance in leadership coaching.

\section{The experienced impact of systems psychodynamics as a coaching stance}

In order to understand the experienced impact of SP as coaching stance, the findings were compared to the following literature on coaching and leadership effectiveness: Bain (1998); Campbell and Huffington (2008); French and Simpson (2015); Meyer and Boninelli (2007); Nohria and Khurana (2010); Passmore et al. (2013); and Sternberg (2007).

Coaching is imbedded in contemporary leadership thinking. Systems psychodynamic leadership coaching facilitated aspects of transformational leadership (Avolio 2007) with 
reference to individualisation and intellectual stimulation as intrapersonal aspects. Systems psychodynamic leadership coaching did not directly address inspirational and idealised influence as interpersonal leadership dimensions. Rather, SPLC focussed on containment leadership (Kilburg \& Diedrich 2007) where leaders become aware of their unconscious representation as the leader in the mind of the system.

Coaching provides a reflectional space. Systems psychodynamic leadership coaching provided opportunities for reflection about leadership (not as only a theory or as competencies, but) as a systemic role managing the boundaries between the rational and irrational, the conscious and unconscious and between the self and the other. Furthermore, SPLC provided a transitional space (Winnicott 2006) for coachees to (1) develop their awareness of and insight into systemic individual (micro-), group (meso-) and organisational (macro-level) behavioural dynamics and (2) to explore their leadership identity in terms of self-representation, behaviour and relationships. Coachees moved from being mostly ignorant unconscious containers of system domain, socially constructed and personal defences, to an openness to experiment with unconscious personal and leadership behaviour. They learned to take up their leadership roles with significantly more self-authorisation and to manage their boundaries with consciousness and rationality. They started to integrate their normative, experiential and phenomenal roles and reported on experiencing more congruence between their introjections and received projections. This indicates a heightened awareness of anxiety as it happens (in the here and now) and the differentiation between 'what [emotionality] is mine and what is not mine'. They illustrated an increased capacity to create new thoughts, to process relatively deep feelings and to venture into conscious and rational action (as part of their adult ego state). Thus, leaders developed a dynamic awareness of their individual identity, how they related to others, what they individually represented in the organisational system and the competence to ask critical questions about the dynamic experiences of the other. These behavioural outcomes are congruent to how SPLC is described in the literature (Beck 2012; Kets de Vries 2014; Macaux 2014; Newton et al. 2006; Passmore et al. 2013; Peltier 2009; Sandler 2011). Some of the reported insights can be framed as moving towards leadership wisdom (Kilburg \& Diedrich 2007), defined as taking up the role with an openness to experience and a creative exploration of own, team and organisational behaviours towards a cognitive understanding, a strong sense of self and a systemic awareness of process and dynamics.

Coaching enhances an understanding of organisational dynamics. Systems psychodynamic leadership coaching facilitated leaders' macro-level insight into the dynamics of the system domain defences of financial organisations, such as narcissism, envy, competition, rivalry and greed (Long 2008). On the meso-level they explored socially constructed defences such as the compulsive dependence on rules, regulations and customs (e.g. in auditing as a profession and in the firm's partner structure). On the micro-level they explored the complexities of their own defensive leadership behaviour, especially their use of denial and projection, and how these dynamics permeated below the surface of consciousness and, as such, influenced their leadership relationships. They explored how they contained emotionality on behalf of the meso-system and practised ways of owning what they experienced as their own.

Coaching facilitates understanding of leadership dynamics and complexity. Systems psychodynamic leadership coaching frames the leadership task as the execution of a dynamic and systemic relational process between leader and follower (Kets de Vries 2014). Coachees started to integrate dynamic concepts into their daily work, for example, the primary task, off-task and anti-task behaviour. This allowed for increased rational self-regulation (Campbell \& Groenbaek 2006) and a here-and-now awareness and realisation of when they were unconsciously colluding or being seduced into serving irrational systemic agendas.

Coaching facilitates the conceptualisation of leadership and its complexity. Systems psychodynamic leadership coaching facilitated coachees' experiential conceptualisation of leadership as consisting of social and political conscious and unconscious dynamics. As leaders, their self-awareness and authorisation facilitated their more effective boundary management between self, other and organisational system (Kets de Vries et al. 2007). In terms of Jaques' (1990) stratified systems theory, postulating how leaders need to deal with increasing levels of complexity as they get promoted up the hierarchy, SPLC seems to have stimulated fourth-order complexity and decision-making. Systems psychodynamic leadership coaching facilitated coachees' conceptualisation of leadership as a dynamic relationship with others and an unconscious relatedness with the system as a whole. Systems psychodynamic leadership coaching stimulated third-order complexity and decision-making. It seems that the clearer explication of leadership as a construct in SP was advantageous in coachees' systemic conceptualisation and dealing with leadership complexity.

Coaching facilitates the construction of a leadership identity. Systems psychodynamic leadership coaching facilitated a systemic awareness and strong efforts to establish an own leadership role boundary enhanced with self and others' authorisation towards realising the coachees' leadership identity (Campbell \& Groenbaek 2006).

Coaching facilitates the transference of leadership competencies and virtues. Systems psychodynamic leadership coaching addressed cognitive, personal and social characteristics and universal leadership virtues such as humanity (kindness, social intelligence) and courage (emotionality, authenticity, bravery, persistence) (Kets de Vries 2014). Systems psychodynamic leadership coaching facilitated leaders' movement from dependence and the denial of their own systemic impact towards working with their independence and ownership in their leadership roles, with some evidence of interdependence (Stapley 2006). 
They became more robust in their exploration of their own and other's behaviours as they explored the effect of their defensive behaviours.

\section{The Kellogg Foundation's indicators for effective leadership}

The Kellogg Foundation indicators (Development Guild 2015) are categorised as individual, organisational, community, field (outcome) and systemic. Systems psychodynamic leadership coaching facilitated behavioural awareness in various aspects of all five indicators. One outstanding element was the coachee's openness to use the self as instrument (Kets de Vries et al. 2007) in the systemic context, meaning to recognise defences such as projections and transferences as they happen. In terms of Sibson Consulting's (O'Malley \& Baker 2012) 12 criteria of effective leadership, SPLC stimulated intent, focus and human significance. Systems psychodynamic leadership coaching additionally stimulated form, representation, imagination, human significance, context and criticism. Less evidence occurred about authenticity, engagement and pleasure (which one would expect to be addressed in positive psychology coaching). It seems that SPLC impacted leadership functioning in terms of selfleadership, leadership of the other (colleagues and followers in dyads and teams) and leadership in the organisation as a system (Greif 2007).

\section{Conclusion}

Professionals in this financial services organisation experienced SPLC as a demanding as well as a fulfilling activity. They explored their own dynamic conscious and unconscious leadership behaviour, how they take up their leadership role, authorise themselves and their colleagues, as well as how they are authorised by the organisational system, manage their boundaries and develop insight into their leadership identity. Systems psychodynamic leadership coaching as methodology created a good-enough container for these professionals to explore, gain a significant level of understanding of and insight into their own anxiety and defensive behaviours to work towards the optimisation of their leader-follower relationships.

The organisation's request for feedback about the impact of $\mathrm{SP}$ as a coaching stance is encapsulated in the discussion section of this article. Measured against guidelines for leadership coaching effectiveness, SPLC seems to comply with most of the set criteria. Although SPLC does not subscribe to a specific leadership theory, it seemed necessary to report back in this manner because of the corporate need to compare coaching inputs for purposes of return on investment.

The limitations of this research are as follows. The literature on SP in leadership coaching is limited, which makes the comparison and confirmation of findings difficult. In terms of design, the contractual restriction of working with only six coaching sessions limited the possibility of a deeper study of coachees' transference of learning to more actual leadership interactions. The thickness of the data may imply that this study reported on too many phenomena in the coachees' experiences, as opposed to focussing on fewer phenomena and giving a deeper rendition of their manifestation.

It was recommended that future research include coaching with other professional fraternities and the experienced difference between professions and that different leadership coaching stances be compared in order to illustrate the strengths and most appropriate application of various models. For this specific organisation, it was recommended that the data from this study should be followed up, for example, in interviews to ascertain the long-term impact of SPLC. A last recommendation is that leaders at partner level be included in the SPLC programme. Apart from providing them with the opportunity to learn about their individual and team dynamics, it would also give a gestalt view of the manifesting SP of this kind of financial services organisation.

\section{Acknowledgements Competing interests}

The author declares that he has no financial or personal relationships that may have inappropriately influenced him in writing this article.

\section{References}

Armstrong, D., 2005, Organisation in the mind. Psychoanalysis, group relations and organisational consultancy, Karnac, London.

Armstrong, D. \& Rustin, M., 2015, Social defences against anxiety, Karnac, London.

Avolio, B.J., 2007, 'Promoting more integrative strategies for leadership theorybuilding', American Psychologist 62(1), 25-33. https://doi.org/10.1037/0003066X.62.1.25
building, Am

Bachkirova, T., 2011, Developmental coaching. Working with the self, Open University Press, Maidenhead.

Bain, A., 1998, 'Social defences against organisational learning', Human Relations 51(3), 413-429. https://doi.org/10.1177/001872679805100309

Beck, U.C., 2012, Psychodynamic coaching. Focus and depth, Karnac, London.

Bennis, W., 2007, 'The challenges of leadership in the modern world', American Psychologist 62(1), 2-5. https://doi.org/10.1037/0003-066X.62.1.2

Bennis, W. \& Sample, S.B., 2015, The art and adventure of leadership, Wiley, New Jersey.

Bion, W.R., 1961, Experiences in groups, Tavistock, London.

Biswas-Diener, R. \& Dean, B., 2007, Positive psychology coaching. Putting the science of happiness to work for your clients, John Wiley, Hoboken, NJ.

Blackman, J.S., 2004, 101 Defences. How the mind shields itself, Brunner-Routledge, New York.

Bluckert, P., 2006, Psychological dimensions of executive coaching, Open University Press, Maidenhead.

Brown, P. \& Brown, V., 2012, Neuropsychology for coaches. Understanding the basics, Open University Press, Maidenhead.

Brunning, H., 2006, Executive coaching. Systems-psychodynamic perspective, Karnac, London.

Campbell, D., 2007, The socially constructed organisation, Karnac, London.

Campbell, D. \& Groenbaek, M., 2006, Taking positions in the organisation, Karnac, London.

Campbell, D. \& Huffington, C., 2008, Organisations connected. A handbook of systemic consultation, Karnac, London.

Chapman, L. \& Cilliers, F., 2008, 'The integrated experiential executive coaching model: A qualitative exploration', South African Journal of Labour Relations 32(1), 63-80.

Cilliers, F., 2005, 'Executive coaching experiences. A systems psychodynamic perspective', South African Journal of Industrial Psychology 31(3), 23-30. https:// doi.org/10.4102/sajip.v31i3.205

Cilliers, F., 2011, 'Positive psychology leadership coaching experiences in a financial organisation', SA Journal of Industrial Psychology/SA Tydskrif vir Bedryfsielkunde 37(1), Art. \#933, 14 pages. https://doi.org/10.4102/sajip.v37i1.933 
Cilliers, F. \& Terblanche, L., 2010, 'The systems psychodynamic leadership coaching experiences of nursing managers', Health SA Gesondheid 15(1), Art \#457, 9 pages. experiences of nursing managers', Health
https://doi.org/10.4102/hsag.v15i1.457

Clarke, S. \& Hoggett, P., 2009, Research beneath the surface. Psycho-Social research methods in practice, Karnac, London.

Clarke, S., Hahn, H. \& Hoggett, P., 2008, Object relations and social relations, Karnac, London.

Colman, A.D. \& Bexton, W.H., 1975, Group relations reader 1, The A.K. Rice Institute. Jupiter, FL.

Colman, A.D. \& Geller, M.H., 1985, Group relations reader 2, The A.K. Rice Institute, Jupiter, FL.

Cooper, C.L., 2005, Leadership and management in the 21st century: Business challenges of the future, Oxford University Press, New York.

Creswell, J.W. \& Plano Clark, V.L., 2011, Designing and conducting mixed methods research, Sage, Los Angeles, CA.

Crevani, L. \& Endrissat, N., 2016, 'Mapping the leadership-as-practice terrain Comparative elements', in J.A. Raelin (ed.), Leadership-as-practice: Theory and application, pp. 21-49, Routledge, New York.

Cytrynbaum, S. \& Noumair, A., 2004, Group relations reader 3, A.K. Rice, Jupiter, FL.

Czander, W.M., 1993, The psychodynamics of work and organizations, Guilford, New York.

Denzin, N.K. \& Lincoln, Y.S., 2005, The Sage handbook of qualitative research, Sage, London.

Development Guild, 2015, viewed 14 May 2015 from http://www.devlopmentguild com

Dippenaar, M. \& Schaap, P., 2017, 'The impact of coaching on the emotional and social intelligence competencies of leaders', South African Journal of Economic and Management Sciences 20(1), a1460. https://doi.org/10.4102/sajems.v20i1.1460

Elkington, R. \& Booysen, L., 2015, 'Innovative leadership as enabling function within organisations: A complex adaptive systems approach', Journal of Leadership Studies 9(3), 78-80. https://doi.org/10.1002/jls.21414

Erskine, R.G., 2010, Life scripts. A transactional analysis of unconscious relational patterns, Karnac, London.

Fraher, A., 2004, A history of group study and psychodynamic organisations, Free Association, London.

French, R. \& Simpson, P., 2015, Attention, cooperation, purpose. An approach to working in groups using insights form Wilfred Bion, Karnac, London.

Grant, A.M., 2007, 'A languishing-flourishing model of goal striving and mental health for coaching populations', International Coaching Psychology Review 2(3), 250-264.

Greif, S., 2007, 'Advances in research on coaching outcomes', International Coaching Psychology Review 2(3), 222-249.

Hawkins, P. \& Smith, N., 2013, Coaching, mentoring and organisational consultancy Supervision and development, Open University Press, Maidenhead.

Hindle, D. \& Sherwin-White, S., 2014, Sibling matters: A psychoanalytic, developmental and systemic approach, Karnac, London.

Hirschhorn, L., 1993, The workplace within: Psychodynamics of organizational life MIT, Cambridge.

Hirschhorn, L., 1997, Reworking authority. Leading and following in the post-modern organisation, MIT Press, London.

Hollway, W. \& Jefferson, T., 2010, Doing qualitative research differently, Sage, Los Angeles, CA.

Huffington, C., Armstrong, A., Halton, W., Hoyle, L. \& Pooley, J., 2004, Working below the surface. The emotional life of contemporary organisations, Karnac, London.

Jaques, E., 1990, Creativity and work, International Universities, Madison, WI.

Kahn, M.S., 2014, Coaching on the axis. Working with complexity in business and executive coaching, Karnac, London.

Kaiser, R.B., Hogan, R. \& Craig, S.B., 2008, 'Leadership and the fate of organisations' American Psychologist 63(2), 96-110. https://doi.org/10.1037/0003-066X.63.2.96

Kets de Vries, M.F.R., 2006, The leader on the couch. A clinical approach to changing people and organisations, Jossey-Bass, Chichester.

Kets de Vries, M.F.R., 2014, Mindful leadership coaching. Journeys into the interior Palgrave Macmillan, London.

Kets de Vries, M.F.R., Korotov, K. \& Florent-Treacy, E., 2007, Coach and couch. The psychology of making better leaders, Palgrave, London.

Kilburg, R. \& Diedrich, R., 2007, The wisdom of coaching: Essential papers in consulting psychology for a world of change, American Psychological Association, Washington, DC

Klein, M., 1997, Envy and gratitude and other works 1946-1963, Vintage, Reading, PA.

Klein, R.H., Rice, C.A. \& Schermer, V.L., 2009, Leadership in a changing world: Dynamic perspectives on groups and their leaders, Lexington Books, Lanham.
Leonard, H.S., Lewis, R.L., Freedman, A.M. \& Passmore, J., 2013, The Wiley-Blackwell handbook of the psychology of leadership, change and organisational development, John Wiley \& Sons, Malden, MA.

Long, S., 2008, The perverse organisation and its deadly sins, Karnac, London.

Macaux, W.P., 2014, 'Coaching the faltering executive', Organisational and Socia Dynamics 14(2), 264-284

Maddi, S.R. \& Khoshaba, D.M., 2005, Resilience at work. How to succeed no matter what life throws at you, AMACOM, New York.

McKenna, D.D. \& Davis, S.L., 2009, 'Hidden in plain sight: The active ingredient of executive coaching', Industrial and Organisational Psychology 2, 244-260. https:// doi.org/10.1111/j.1754-9434.2009.01143.x

McLeod, J., 2012, Case study research in counselling and psychotherapy, Sage, Los Angeles, CA.

Meyer, T.N.A. \& Boninelli, I., 2007, Conversations in leadership, South African perspectives, Knowres, Randburg.

Motsoaledi, L. \& Cilliers, F., 2012, 'Executive coaching in diversity from the systems psychodynamic perspective', SA Journal of Industrial Psychology/SA Tydskrif vir Bedryfsielkunde 38(2), Art. \#988, 11 pages. https://doi.org/10.4102/sajip.v38i2.988

Neumann, J.E., Keller, K. \& Dawson-Shepherd, A., 1997, Developing organisationa consultancy, Routledge, London.

Newton, J., Long, S. \& Sievers, B., 2006, Coaching in depth. The organisational role analysis approach, Karnac, London.

Nohria, N. \& Khurana, R., 2010, Handbook of leadership theory and practice, Harvard Business Press, Boston, MA

Northouse, P.G., 2014, Leadership: Theory and practice, Sage, Thousand Oaks, CA.

O'Malley, M. \& Baker, W.F., 2012, The 12 criteria of effective leadership, Perspective 20, December, viewed 06 April 2015, from http://www.sibson.com/publications

Obholzer, A. \& Roberts, V.Z., 1994, The unconscious at work, Routledge, London.

Page, N. \& De Haan, E., 2014, 'Does executive coaching work?', The Psychologist 27(8), $582-586$

Paice, L., 2012, New coach. Reflections from a learning journey, Open University Press, Maidenhead.

Passmore, J., Peterson, D.B. \& Freire, T., 2013, The Wiley-Blackwell handbook of the psychology of coaching and mentoring, Wiley-Blackwell, Chichester.

Peltier, B., 2009, The psychology of executive coaching. Theory and application Brunner-Routledge, New York.

Sandler, C., 2011, Executive coaching. A psychodynamic approach, McGraw Hill, Maidenhead.

Schafer, R., 2003, Insight and interpretation. The essential tools of psychoanalysis, Karnac, London.

Sievers, B., 2009, Psychoanalytic studies of organisations, Karnac, London.

Stapley, L.F., 2006, Individuals, groups and organisations beneath the surface, Karnac, London.

Sternberg, R.J., 2007, 'Foreword to the special issue on leadership', American Psychologist 62(1), 1. https://doi.org/10.1037/0003-066X.62.1.1

Stout Rostron, S., 2009, Business coaching. Wisdom and practice. Unlocking the secrets of business coaching, Knowledge Resources, Randburg.

Tangolo, A.E., 2015, Psychodynamic psychotherapy with transactional analysis, Karnac, London.

Terre Blanche, M., Durrheim, K. \& Painter, D., 2006, Research in practice. Applied methods for the social sciences, UCT Press, Cape Town.

Thorne, S., 2016, Interpretive description. Qualitative research for applied practice, Routledge, New York.

Tudor, K. \& Summers, G., 2014, Co-creative transactional analysis. Papers, responses, dialogues, and developments, Karnac, London.

Vansina, L.S. \& Vansina-Cobbaert, M., 2008, Psychodynamic for consultants and managers. From understanding to leading meaningful change, Wiley-Blackwell, Chichester.

Veldsman, T.H. \& Johnson, A.J., 2016, Leadership: Perspectives from the front line, KR Publishing, Randburg.

Wagner, C., Kawulich, B.B. \& Garner, M., 2012, Doing social research. A global context, McGraw-Hill, New York.

Western, S., 2012, Coaching and mentoring. A critical text, Sage, Los Angeles, CA.

Western, S., 2013, Leadership. A critical text, Sage, Los Angeles, CA

Wilson, S. \& MacLean, R., 2011, Research methods and data analysis for psychology, McGraw-Hill, London.

Winnicott, D.W., 2006, The family and individual development, Routledge, London.

Wolcott, B.L., 2001, Writing up qualitative research, Sage, London. 